\title{
SURGICAL APPROACHES TO RECURRING TORSIONS AND THE EFFECTS OF THE ATTACKS ON THE OVARIAN RESERVE: A CASE STUDY IN LIGHT OF THE LITERATURE
}

\author{
Ayla UCKUYU' ${ }^{1}$, Erdem TURHAN ${ }^{1}$, F. Ceylan CIFTCI' ${ }^{1}$, Hulusi B. ZEYNELOGLU ${ }^{2}$ \\ ${ }^{1}$ Department of Obstetrics and Gynecology, Baskent University, Faculty of Medicine, Konya, Turkey \\ 2 Department of Obstetrics and Gynecology, Baskent University, Faculty of Medicine, Ankara, Turkey
}

\begin{abstract}
SUMMARY
Objective: To report the effects of the torsion attacks on the ovarian reserve, and to present the surgical approach in cases of ovary torsion that develop after preventive surgery.

Design: The presentation of the case.

Setting: University hospital.

The patient: The sixteen-years-old girl, who had lost her right adnexa because of torsion, suffered successive torsion in the left adnexa after preventive surgery.

Intervention: Through the laparoscopic method, the utero-ovarian ligament was shortened and ovariopexy was applied to the back of the uterus. The ovarian reserve between the attacks was monitored.

Main Outcome Measure: The prevention of recurring torsions through the surgical method and thereby the preservation of the ovarian reserve.

Result: The ovary must be protected under all circumstances during the treatment of torsion. More than one method of adnexa fixation may prove necessary to prevent further attacks.

Conclusion: The case we present here is the unique in which the two sides were successively affected, despite the surgical intervention to prevent any recurrence, and also the unique in which the ovarian reserve between the attacks was monitored. Apparently, the ovarian reserve is affected badly by recurrent torsion attacks. The ovarian reserve tests indicate some improvement in the months following the last attack.
\end{abstract}

Key words: anti-müllerian hormone, laparoscopy, oophoropexy, ovarian reserve, ovariopexy, recurrent ovarian torsion

Journal of Turkish Society of Obstetrics and Gynecology, (J Turk Soc Obstet Gynecol), 2013; Vol: 10, Issue: 1, Pages: 48- 52

\section{TEKRARLAYAN TORSIYONLARDA CERRAHİ YAKLAŞIMLAR VE OVER REZERVINE ETKİLERİ, LITERATUR IŞIĞINDA OLGU SUNUMU}

\section{ÖZET}

Objektif: Torsiyon önleyici cerrahi sonrası gelişen over torsiyonu vakasında cerrahi yaklaşımı ve atakların over rezervi üzerine etkilerini bildirmek.

Planlama: Olgu sunumu

Ortam: Üniversite Hastanesi

Hasta: Torsiyon nedeniyle sağ adneksini kaybetmiş 16 yaşındaki kız torsiyon önleyici cerrahi sonrası ardışık sol adneksa torsiyonu geçirdi.

Girişim: Laparaskopik yolla utero ovaryan ligament kısaltılması ve uterus arka yüzüne ovariopeksi ameliyatı yapıldl.

Address for Correspondence: Dr. Ayla Üçkuyu. Başkent Üniversitesi Tıp Fakültesi, Jinekoloji ve Obstetrik Anabilim Dalı, Konya, Turkey Phone: + 90 (532) 5756552

e-mail: uckuyuayla@gmail.com

Received: 30 December 2011, revised: 05 August 2012, accepted: 28 August 2012, online publication: 30 August 2012 
Bu ataklar arasinda over rezervi takip edildi.

Değerlendirme parametreleri: Torsiyon tekrarlarınin cerrahi yolla önlenerek over rezervinin korunmasl.

Sonuç: Torsiyon tedavisinde over her koşulda korunmalıdır, ataklarının önlenmesi için birden fazla adneks fiksasyon yöntemi kullanılması gerekebilir.

Yorum: Sunduğumuz vaka, iki taraflı ardışı, bir torsiyon önleyici cerrahiye rağmen yenileyen ve ataklar arasında over rezervi takip edilen tek vakadır. Over rezervi çoklu torsiyon ataklarından kötü etkilenmekte ve rezerv testleri atağı takipeden aylarda klsmen düzelmektedir.

Anahtar kelimeler: antimülleryan hormon, laparoskopi, tekrarlayan adneks torsiyonu, ooforopeksi, ovariopeksi, over rezervi,

Türk Jinekoloji ve Obstetrik Dernĕgi Dergisi, (J Turk Soc Obstet Gynecol), 2013; Cilt: 10, Sayl: 1, Sayfa: 48- 52

\section{INTRODUCTION}

Adnexal torsion is the rotation of ovary or fallopian tube on its own ligamentous structure(1). Bilateral successive torsion is not frequent in the literature, with only a few reported cases(2). Early diagnosis and immediate surgical treatment play important role in preserving ovarian functions in the long term ${ }^{(3)}$. Current approach in the management is conserving ovary by performing detorsion and additionally oophoropexy irrespective of macroscopic appearance of the ovary (3). In this report, the case of recurrent bilateral adnexal torsion is presented along with our observations on the effects of multiple torsion episodes on ovary reserve.

\section{CASE}

A 16 year old single female applied to emergency service with intermittent abdominal pain in the left lower quadrant persisting for two days in March-2008. Her fever was 37.8 $\mathrm{C}^{\circ}$, white blood cell (WBC): $15.800 \mathrm{~K} / \mathrm{micL}$ and $\mathrm{C}$ reactive protein (CRP):76,8 mg/L. The physical examination revealed the findings of acute abdomen. In ultrasonography (USG), there was a $58 \mathrm{~mm}$ cyst in left ovary and significantly increase in the volume of the ovarian stroma compared to the right ovary. $\beta$-hCG and $\alpha$-feto protein values were in the normal range. Then the patient underwent a diagnostic laparoscopy with the presumptive diagnosis of torsion. In the surgical exploration, left adnexa was found to be torsioned twice around its long axis and appeared purplish-black with edematous increased in the volume. Despite it was detorsioned, its colour did not change and intraoperative Doppler ultrasonography showed no vascular flow, the diagnosis was considered to be adnexal necrosis and a salpingo-oophorectomy was carried out. Pathology results were ovary/fallopian tube that contained haemorrhagia and congestion.
The patient applied to the emergency service again 18 months later, in October-2009, because of recurrence of the symptoms. Patient underwent emergency laparoscopy with the presumptive diagnosis of recurrent torsion. In the surgery, right adnexa had twisted once and fallopian tube was in blue colour, however, the colour of ovary looked almost normal. Adnexa was detorsioned. During the surgery, the fallopian tube was observed to return to its normal colour. It came to the surgeons' attention that utero-ovarian and infindibulopelvic ligaments were excessively long. In order to prevent adnexa retorsion, Endostich (Tyco Healthcare, Norwalk, Connecticut, USA) was utilized to shorten utero-ovarian ligament with two separate 0-2 vicryl (absorbable) sutures passing from its distal and proximal ends. On postoperative $6^{\text {th }}$ month, the size of ovary and the number of antral follicles were normal in the ultrasonographic examination and the patient had regular menstruations.

The patient was hospitalized again11 months after the second surgery, in September- 2010, because of recurrence of the same symptoms. When no flow was seen in colour and pulse Doppler, torsion was the preoperative diagnosis and patient underwent emergency laparoscopy again. It was seen that right adnexa was twisted twice and consequently ovary size reached $90 \mathrm{~mm}$ and it was congested, haemorrhagic and fragile. Adnexa was detorsioned. It was observed that the colour of the fallopian tube improved immediately. Despite the previous surgeries, it was surprising that there was no adhesion on serosal surfaces. There was no even trace of previous plication sutures on utero-ovarian ligament. Likewise, there was no adhesion in the previous adnexectomy area. Because previous ligament plication attempt failed and ovary was congested, haemorrhagic and appeared fragile, therefore it was decided that different oophoropexy technique and another time should be implemented, 
so that the ovary would not be harmed.

One month after 3rd torsion episode, in October-2010, patient underwent laparoscopy for elective oophoropexy. In the ovary, a simple cyst of $30 \mathrm{~mm}$ was aspirated. Two different oopheropexy techniques were applied using nonabsorbable suture materials. Firstly, utero-ovarian ligament triplication was carried out with intracorporal running stitch using 2-0 Ethibond Excel (Ethicon,Johnson \& Johnson Intl. St- Stevens-Woluwe, Belgium).Then, ovary was fixed to the posterior of uterus with 2-0 prolene (Ethicon,Johnson \& Johnson Intl. St- Stevens-Woluwe, Belgium) with double suture passage (figure 1). Ovarian reserve tests of the patient after torsion episodes are shown in the Table I. In the third month, the size of the ovary was $44 \times 35 \times 20 \mathrm{~mm}$

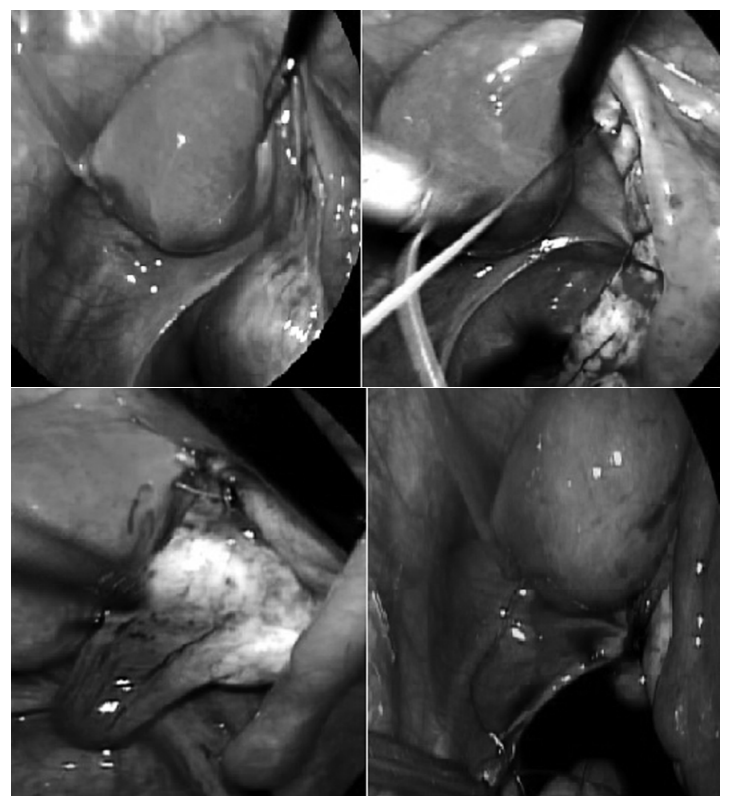

Figure 1: Oophoropexy; triplication of the utero-ovarian ligament, and ovariopexy; fixation of the ovary to the posterior uterus serosa.

\section{DISCUSSION}

At present, detorsion is considered as the optimal management of ovarian torsion. Adnexal detorsion should be done and also ovary should be preserved by ignoring the appearance of ovary in the surgery ${ }^{(4)}$. There is no correlation between the macroscopic appearance of ovary with torsion during operation, recovery and functions $(5)$. If there is excessive edema or hemorrhagia in the gonad, interventions other than detorsion should be performed under elective conditions in a second operation in order to minimize the risk of ovary being injured. Even if the gland with torsion is markedly inflamed and ischemic, there should be no hesitation in only carrying out detorsion of the ovary $(2,3)$. In this situation, the patient should be followedup through ultrasound examinations and tumor markers. Interval laparoscopy and tumorectomy or cystectomy, and possible oophoropexy should be performed after the edema has resolved in 6 to 8 weeks ${ }^{(3)}$.

In order to enable the fixation of ovary and prevent recurrence of ovarian torsion, several surgical techniques have been suggested. One of these techniques is the triplication of utero ovarian ligament described by Germain et $\mathrm{al}^{(6)}$. In this technique, uteroovarian ligament is plicated with continuous suture and shortened. Other techniques also have been used. Ovariopexy techniques have been used, in which, ovary is sutured to the peritoneum of posterior abdominal wall, to pelvic sidewall, over broad ligament or to posterior uterus serosa. There are also oophoropexy operations, which involve the suturation of uteroovarian ligament either to the posterior aspect of the

Table I: Clinic, surgical and hormonal characteristics of the patient according to torsion episodes.

\begin{tabular}{|c|c|c|c|c|}
\hline Events & Surgical procedure & FSH mIU/ml & E2 Pg/ml & AMH $\mathrm{ng} / \mathrm{ml}$ \\
\hline $\begin{array}{l}\text { First torsion episode, } \\
\text { March-2008 }\end{array}$ & L/S left salpingo oophorectomy & & & \\
\hline \multirow[t]{2}{*}{$\begin{array}{l}\text { Second torsion episode, } \\
\text { October-2009 }\end{array}$} & $\begin{array}{l}\mathrm{L} / \mathrm{S} \text { right adnexal } \\
\text { detorsion }+ \text { utero ovarian } \\
\text { ligament plication }\end{array}$ & $\begin{array}{l}1 \text { month later } \\
4,8\end{array}$ & $\begin{array}{l}1 \text { month later } \\
98\end{array}$ & \\
\hline & & $\begin{array}{l}6 \text { months later } \\
3,8\end{array}$ & $\begin{array}{l}6 \text { months later } \\
52\end{array}$ & \\
\hline \multirow[t]{4}{*}{$\begin{array}{l}\text { Third torsion episode, } \\
\text { September- } 2010\end{array}$} & $\begin{array}{l}\mathrm{L} / \mathrm{S} \text { right adnexal } \\
\text { detorsion, } 1 \text { month later }\end{array}$ & $\begin{array}{l}1 \text { month later } \\
8.7\end{array}$ & $\begin{array}{l}1 \text { month later } \\
36\end{array}$ & $\begin{array}{l}1 \text { month laterl } \\
0.2\end{array}$ \\
\hline & elective oophoropexy; & 3 months later & 3 months later & 3 months later \\
\hline & triplication of utero-ovarian & 4.4 & 70 & 0,8 \\
\hline & $\begin{array}{l}\text { ligament with Ethibond, ovariopexy } \\
\text { with prolene. }\end{array}$ & & & $\begin{array}{l}6 \text { months later } \\
\text { (March-2011) } \\
1,2\end{array}$ \\
\hline
\end{tabular}


uterus or to the lateral pelvic wall(2,6-10).If the patients have a single ovary (due to congenital absence, spontanous amputation or previous operation), in order to protect it, ovary should absolutely be fixed, in addition to detorsion $(9,11,12)$.

In patients with long utero-ovarian ligament, ligament should be plicated or shortened( ${ }^{(6)}$. In this technique, permanent suture should be used. In recurrent torsion cases on the ipsilateral side, in order to provide permanent fixation, proximal ovarian pole has been sutured to the abraded peritoneum of the pelvic sidewall (2). It is very rare in the literature the case of recurrent torsion, which has been carried out operation once to prevent torsion. In a paper, an 8 year old prepubertal girl has been reported to have recurrent torsion 1 year after gonadopexy to the lateral pelvic wall(2). The suture that they used was absorbable. This type of suture was used by other authors as well; however no other recurrence was reported(7). In this case which has long utero-ovarian ligament, retorsion was observed in the same side after shortening ligament with absorbable suture. In addition to long ligamentous structures of the ovary and uterus, the lack of adhesion formation on the peritoneum in spite of previous pelvic surgery (she underwent shortening of utero-ovarian ligament and oophorectomy) was interesting the patient. In articles of recurrent torsion cases, pelvic adhesion was not reported in any case at second laparoscopic observation ${ }^{(2,7)}$.

Asynchronous bilateral ovarian torsion occurs even with no underlying adnexal pathology. It is likely that these patients have underlying anatomic variations such as excess mobility of the adnexa due to an abnormally long ligaments or the lack of adhesion formation on the peritoneum ${ }^{(7)}$. Decreased adhesion may contribute to the increased risk of ovarian torsion. In patients with pelvic floor disorders, it was demonstrated that a collagen disorder as a gene polymorphisms coding type 3 collagen may play a role etiology ${ }^{(13)}$. Thus the changes in collagen also could play an important role etiology of abnormally long ligaments like in all patients with pelvic floor disorders. Adhesion formation that is a kind of fibrosis is involved in collagen metabolism ${ }^{(14)}$. Although we have not searched any abnormality of collagen, underlying etiology may be a collagen disorder in this patient.

All surgical interventions to the ovary decrease the follicle pool in the ovary, hence it limits the reproductive potential of the woman. Tissue hypoxia that caused by torsion may also decrease ovary reserve by leading to necrosis in ovary tissue. Plication of uteroovarian ligament may compromise minimally ovarian blood as it may interfere minor blood supply which passes through the ligament, however this may be negligible(15).

Serum Anti-Müllerian hormone (AMH) level has been suggested to be a reliable marker of ovarian reserve. It was revealed that there is a decrease of $40 \%-60 \%$ in ovary reserve tests after cystectomy carried out for endometrioma or other cysts of one sided oophorectomy $(16,17)$. The changes in reserve tests of the ovary in recurrent torsions have not been reported in the current literature(2,7). However, in these articles, regular menstruation and spontaneous or IVF pregnancies were reported after detorsion. In this case, we followed AMH and FSH levels between recurrent torsion attacks. We observed that FSH increased in acute period and then returned to normal levels. It is known that primordial follicles of ovary are resistant to stress, while growing follicles are vulnerable to stress ${ }^{(18)}$. AMH is produced by the granulosa cells of early developing follicles in the ovary. AMH reflects the quantity of the ovarian follicle pool. In patients with premature ovarian failure, $\mathrm{AMH}$ is undetectable ${ }^{(19)}$. In this case, between torsion attacks, FSH values were within normal range. Although AMH was not evaluated between torsion attacks, it was found at very low level $(0.2 \mathrm{ng} / \mathrm{ml})$ one month after the last attack. Our patient had spontaneous regular menstruation after operation. At $3^{\text {th }}$ month and $6^{\text {th }}$ month, marked increase was found in AMH level $(0,8 \mathrm{ng} / \mathrm{ml}$ and $1,2 \mathrm{ng} / \mathrm{ml}$ respectively). This may be explained as follows: the number of primary follicles and preantral follicles releasing AMH decrease with the effect of ischemia, but there is probably no pronounced decrease in the number of primordial follicles, which are more resistant to stress. After the trauma subsides, initial recruitment begins and 3 months later, the number of primary and preantral follicles increase again ${ }^{(19)}$. Improvement in AMH levels after 3 months ovary injury, was also shown after cystectomy(17).

In summary, ovariopexy procedure that was carried out on the posterior aspect of uterus with non absorbable suture may be a satisfactory fixation method, which also protects anatomic and functional relation between the fallopian tube and ovary. Even though long terms results are not yet known, recurrent torsion attacks will have an adverse effect on ovarian reserve. In the treatment of torsion, it is necessary to preserve ovary under all conditions and to prevent recurrence. 


\section{REFERENCES}

1. Oelsner G, Shashar D. Adnexal torsion. Clin Obstet Gynecol 2006; 49: 459- 63 .

2. Fuchs N, Smorgick N, Tovbin Y, Ben Ami I, Maymon R, Halperin R et al. Oophoropexy to Prevent Adnexal Torsion: How, When, and for Whom? J Minim Invasive Gynecol 2010; 17: 205-8

3. Darrell L, Cass MD. Ovarian torsion. Seminars in Pediatric surgery. $2005 ; 14: 86-92$

4. Eckler K, Laufer MR, Perlman SE. Conservative management of bilateral asynchronous adnexal torsion with necrosis in a prepubescent girl. J Pediatr Surg 2000; 35: 1248- 51 .

5. Oelsner G, Cohen SB, Soriano D, Admon D, Mashiach S, Carp H. Minimal surgery for the twisted ischaemic adnexa can preserve ovarian function. Hum Reprod 2003; 18: 2599 602.

6. Germain M, Rarick T, Robins E. Management of intermittent ovarian torsion by laparoscopic oophoropexy. Obstet Gyneco 1996; 88: 715- 7

7. Abes M, Sarihan H. Oophoropexy in children with ovarian torsion. Eur J Pediatr Surg 2004; 14: 168- 71.

8. Houry D, Abbott JT. Ovarian torsion: a fifteen-year review. Ann Emerg Med 2001; 38: 156- 9

9. Ozcan C, Celik A, Ozok G, Erdener A, Balik E. Adnexal torsion in children may have a catastrophic sequel: asynchronous bilateral torsion. J Pediatr Surg 2002; 37: 1617- 20.

10. Djavadian D, Braendle W, Jaenicke F. Laparoscopic oophoropexy for the treatment of recurrent torsion of the adnexa in pregnancy: case report and review. Fertil Steril 2004; 82: 933- 6

11. Crouch NS, Gyampoh B. Cutner AS, Creighton SM. Ovarian torsion: to pex or not to pex? Case report and review of the literature. J Pediatr Adolesc Gynecol 2003; 16: 381- 4.

12. Shun A. Unilateral childhood ovarian loss: an indication for contralateral oophoropexy? Aust N Z J Surg 1990; 60: 791-

13. Kluivers KB, Dijkstra JR, Hendriks JC, Lince SL, Vierhout ME, van Kempen LC. COL3A1 2209G>A is a predictor of pelvic organ prolapse. Int Urogynecol J Pelvic Floor Dysfunct 2009; 20: 1113-8.

14. Vural B, Canturk NZ, Esen N, Solakoglu S, Canturk Z, Kirkali $\mathrm{G}$, at al. The role of neutrophils in the formation of peritoneal adhesions. Hum Reprod 1999; 14: 49-5 4.

15. Tropeano G, Di Stasi C, Litwicka K, Romano D, Draisci G, Mancuso S. Uterine artery embolization for fibroids does not have adverse effects on ovarian reserve in regularly cycling women younger than 40 years. Fertil Steril 2004; 81: 105561

16. Lee DY, Young Kim N, Jae Kim M, Yoon BK, Choi D. Effects of laparoscopic surgery on serum anti-mullerian hormone levels in reproductive-aged women with endometrioma. Gynecol Endocrinol. 2010; [Epub ahead of print]

17. Chang HJ, Han SH, Lee JR, Jee BC, Lee BI, Suh CS, et al. Impact of laparoscopic cystectomy on ovarian reserve: serial changes of serum anti-Mullerian hormone levels. Fertil Steril 2010; 94: 343- 9 .

18. La Marca A, Broekmans FJ, Volpe A, Fauser BC, Macklon NS. Anti-Müllerian hormone (AMH): what do we still need to know? Hum Reprod 2009; 24: 2264- 75

19. Shenns RJ. Gonadal dysfunction. In: DeVita VT Jr, Hellman S, Rosenberg SA. eds. Cancer - Principles \& Practice of Oncology J.B. Lippincott Co, Philadelphia, 1993: 2395- 406. 